Article

\title{
Chemical Fingerprint of 'Oblačinska' Sour Cherry (Prunus cerasus L.) Pollen
}

\author{
Milica Fotirić Akšić ${ }^{1, *}$, Uroš Gašić ${ }^{2}$, Dabić Zagorac Dragana ${ }^{3}$, Milica Sredojević ${ }^{3}$, \\ Tomislav Tosti ${ }^{2}$, Maja Natić ${ }^{2}$ and Mekjell Meland ${ }^{4}$ \\ 1 Faculty of Agriculture, University of Belgrade, Nemanjina 6, 11080 Belgrade, Serbia \\ 2 Faculty of Chemistry, University of Belgrade, Studentski trg 16, 11000 Belgrade, Serbia \\ 3 University of Belgrade, Innovation Center, Faculty of Chemistry, Studentski trg 16, 11000 Belgrade, Serbia \\ 4 Norwegian Institute of Bioeconomy Research-NIBIO Ullensvang, 5781 Lofthus, Norway \\ * Correspondence: fotiric@agrif.bg.ac.rs; Tel.: +381642612710
}

Received: 29 June 2019; Accepted: 19 August 2019; Published: 21 August 2019

check for updates

\begin{abstract}
The aim of this research was to analyze sugars and phenolics of pollen obtained from 15 different 'Oblačinska' sour cherry clones and to assess the chemical fingerprint of this cultivar. Carbohydrate analysis was done using high-performance anion-exchange chromatography (HPAEC) with pulsed amperometric detection (PAD), while polyphenols were analyzed by ultra-high-performance liquid chromatography-diode array detector-tandem mass spectrometry (UHPLC-DAD MS/MS) system. Glucose was the most abundant sugar, followed by fructose and sucrose. Some samples had high level of stress sugars, especially trehalose. Rutin was predominantly polyphenol in a quantity up to $181.12 \mathrm{mg} / \mathrm{kg}$ (clone III/9), with chlorogenic acid (up to $59.93 \mathrm{mg} / \mathrm{kg}$ in clone III/9) and $p$-coumaric acid (up to $53.99 \mathrm{mg} / \mathrm{kg}$ in clone VIII/1) coming after. According to the principal component analysis (PCA), fructose, maltose, maltotriose, sorbitol, and trehalose were the most important sugars in separating pollen samples. PCA showed splitting off clones VIII/1, IV/8, III/9, and $\mathrm{V} / \mathrm{P}$ according to the quantity of phenolics and dissimilar profiles. Large differences in chemical composition of studied 'Oblačinska sour cherry' clone pollen were shown, proving that it is not a cultivar, but population. Finally, due to the highest level of phenolics, clones IV/8, XV/3, and VIII/1 could be singled out as a promising one for producing functional food and/or in medicinal treatments.
\end{abstract}

Keywords: clone; carbohydrates; 'Oblačinska' sour cherry; phenolics; pollen

\section{Introduction}

Pollen, a microgametophyte in seeded plants, is one of the most important reproductive plant products because it carries spermatic cells, which are necessary in double fertilization and, thus, in population sustainability. It develops in androeceum, where tapetum cells regulate sugar transport in the whole anther mostly nourishing pollen grains [1]. During flowering time pollen grains are fully developed having reserves that are necessary for pollen germination and fusion with a female gamete $[2,3]$. When it falls on a sticky stigma, a pollen tube starts to grow through the transmitting tissue of the pistil (using sugars and energy), and if the crossing combination is compatible it reaches the embryo sac that contains the egg cell.

The chemistry of pollen grains differs due to the botanical and geographic origin, edaphic and environmental parameters (temperature, water, and light intensity), and type of pollination and pollinizers [4]. Carbohydrates, mostly polysaccharides (starch, callose, pectin, cellulose, and sporopollenin) and low molecular sugars (fructose, glucose, and sucrose) are one of the important components of pollen grains and constitute between 13 and $55 \%$ of pollen $[5,6]$. Content of starch can be in range from 3.6 to $13 \%$, hydrated short-lived pollen grains have high level, and dry long-lived 
pollen grains have very low level (but high in sucrose) [7]. Pollen grains store high level of minerals, which can vary from 2.5 to $6.5 \%$ of pollen dry weight. The highest portion goes to nitrogen $(0.36 \%$ to 9.7\%), while other important minerals are $\mathrm{K}, \mathrm{Mg}, \mathrm{P}, \mathrm{Ca}, \mathrm{S}, \mathrm{B}, \mathrm{Zn}, \mathrm{Cu}, \mathrm{Mn}$, and Fe [8]. Pollen grains are a rich source of amino acids, and the six most common are aspartic acid, glutamic acid, proline, leucine, lysine, and arginine, comprising 60\% of protein. Proline is the most abundant and can account for 1 to $2 \%$ of the whole pollen grain weight [9]. Protein is estimated from 10 to $40 \%$ (and directly influences the bee body's largeness), while being poorest in anemoflimous gymnosperms [10].

Pollen has up to $10 \%$ of lipids, where fatty acids are nutritionally important for pollinators [11]. Anemomphilous plants have the lowest level of lipids in pollen, while pollen-feeder-zoophilus plants have the highest [12]. Up to $60 \%$ of fatty acids are unsaturated acids (oleic, linoleic, and linolenic), while palmitic acid is the most common among the saturated [13]. It is observed that pollen can have compounds that are toxic to some insects or even to bees, and the contents are species dependent [14]. In most cases those are alkaloids, phenolics, and cyanogenic glycosides, which role is to promote pollinators constancy, defense pollen from non-pollinators, and reduce pollinator infection with antimicrobial property [15-18]. Beside all of this, pollen contains $\sim 20 \%$ of water, but some grasses can have up to $50 \%$ [19]. Rest of the constituents, such as sterols, vitamins ( $\beta$-carotene, B1; B2; B3; B5; B6; C, H; folic acid, and E), enzymes, hormones, and terpenes are also essential for bees [20-22].

Besides floral scents and visual stimuli, nectar and pollen chemistry and morphology are the most common flower traits that attract bees [23-25]. Nectar and pollen that are used as nourishment to pollinators represent a reward to pollinators and are a key element in the plant-insect interaction [26]. The highest nutritive value for bees has pollen originating from the genera Crocus, Salix, Papaver, Trifolium, Castanea, Raphanus, Sinapis, Erica, and from fruit trees [5]. Pollen is used as a food during developmental stages in the hive, reproduction, brood rearing, body size, venom production, and longevity [27]. Pollen is also directly influencing the physiological metabolism of bees and its tolerance to pathogens and pesticides [28,29]. When collected by bees, pollen is not consumed immediately, but it is stored in beehive cells, mixed with honey, nectar, and glandular secretions, undergoes lactic fermentation, and becomes 'bee bread' [30].

In recent years pollen has been investigated by many scientists who considered it as a natural source of healthy food, energy, and functional components for human consumption [31-33]. Pollen was proved to have therapeutic properties, having high antioxidative, antiinflammatory, antianaemic, anticarcinogenic, antiallergenic, antiradiation, and antitoxic capacities [34-36]. Earlier, pollen was used to treat benign prostatic hyperplasia but now it is shown that pollen regulates the digestive and respiratory systems, enhances the cardiovascular system and blood vessel maintenance by preventing arteriosclerosis, has positive effects on bone tissue, building up immunity, and helps in wound healing and age-delaying [37-39]. Even Al-Salem et al. suggested that pollen has positive effect on treating neuroinflammation, and thus can be used against autism [40]. Besides, Prunus sp. and Rubus sp. pollen ethanolic extracts showed antimicrobial activity against Erwinia carotovora (subsp. carotovora) and Xanthomonas campestris that are economically important pests of agricultural crops [41].

Sour cherry is a very important fruit species in Serbia. The total acreage is $\sim 17,500$ ha with a production of 91,659 MT. It is ranked as third in the country (after plum and apple) and sixth in the world based on tonnage [42]. The most important cultivar is the 'Oblačinska' sour cherry that accounts for about $85 \%$ of total Serbian production, which fruits are mostly exported as frozen or canned to Western European countries. It is proved and accepted that the 'Oblačinska' sour cherry is not a cultivar but a mixture of different clones that vary in many morphological, pomological, and chemical traits [43-45]. Sour cherry is an autogamous and entomophilous fruit species, which means that insects are needed to transfer pollen to stigma in order to obtain sufficient quantity and quality of sour cherry fruits. Therefore, bearing in mind the complex chemical composition of pollen, the aim of this study was to analyze and compare the sugars, sugar alcohols, and phenolic content of pollen grains obtained from different 'Oblačinska' sour cherry clones in two years. As far as we know, this is the first study where pollen was gathered by hand from different sour cherry genotypes. Obtained data will help 
us create a chemical fingerprint of this important sour cherry cultivar, which can be further used as product rich in bioactive compounds and used as a functional food.

\section{Materials and Methods}

\subsection{Sample Collection}

Pollen of 15 different 'Oblačinska' sour cherry clones were collected from the Experimental Station 'Radmilovac', which is part of the Faculty of Agriculture, University of Belgrade, Serbia. The orchard was located $8 \mathrm{~km}$ north-east of Belgrade $\left(44^{\circ} 45^{\prime} \mathrm{N} ; 20^{\circ} 35^{\prime} \mathrm{E}\right.$, at $135 \mathrm{~m}$ altitude). Orchard planting and orchard maintenance are described in Guffa et al. [45]. Each clone in the orchard was represented by a single tree.

Pollen was gathered in two consecutive years (2015 and 2016). At the balloon stage (code 59, $\mathrm{BBCH}$ (in German: Biologische Bundesanstalt, Bundessortenamt und CHemische Industrie) scale [46]), which in the temperate region starts at the beginning of April, twigs with flowers from three scaffolds (with different orientation) from each 'Oblačinska' sour cherry clone were collected, transported to the laboratory, placed in jars with water, and kept at room temperature $\left(22 \pm 2{ }^{\circ} \mathrm{C}\right)$. From unopened flowers, anthers were collected in Petri dishes just before dehiscence. Unopened anthers were dried at room temperature for $24 \mathrm{~h}$ until shedding of pollen started. Afterwards, the closed dish was moved for 2 to 3 min left-and-right, in circles, and up-and-down, by hand, to cause vibration throughout the whole area, in order to increase anther breakage and pollen releasing. Empty anthers were removed with a dissecting needle. After, Petri dishes with just pollen inside were kept frozen at $-18{ }^{\circ} \mathrm{C}$ until chemical analysis.

\subsection{Chemicals}

Acetonitrile and formic acid (both MS grade), methanol (high-performance liquid chromatography, HPLC grade), sodium hydroxide, sodium acetate, and hydrochloric acid were purchased from Merck (Darmstadt, Germany). Ultra-pure water (Thermofisher TKA MicroPure water purification system, $0.055 \mu \mathrm{S} / \mathrm{cm}$; Bremen Germany) was used to prepare standard solutions and blanks. The solid phase extraction (SPE) cartridges used to concentrate the samples were Strata C18-E (500 mg/3 mL) obtained from Phenomenex (Cluster d.o.o., Belgrade, Serbia). Syringe filters ( $25 \mathrm{~mm}$, nylon membrane, $0.45 \mu \mathrm{m}$ ) were purchased from Psi lab d.o.o. (Belgrade, Serbia). Filter paper (Whatman No.1) was supplied by Merck.

Phenolic standards (protocatechuic acid, $p$-hydroxybenzoic acid, vanillic acid, syringic acid, ellagic acid, chlorogenic acid, caffeic acid, $p$-coumaric acid, ferulic acid, sinapic acid, cinnamic acid, rutin, hyperoside, cynaroside, apiin, naringin, astragalin, catechin, luteolin, apigenin, naringenin, kaempferol, aesculin, phloridzin, coniferyl aldehyde, and aesculetin) were supplied by Sigma Aldrich (Steinheim, Germany).

Sugar standards (trehalose, arabinose, glucose, fructose, sucrose, isomaltotriose, turanose maltose, and maltotriose) were purchased from Tokyo Chemical Industry (TCI, Europe, Belgium). Standard of sorbitol was obtained from Sigma Aldrich (Steinheim, Germany).

\subsection{Sample Preparation}

Pollen from each clone $(0.5 \mathrm{~g})$ was measured on an analytical balance and suspended in $10 \mathrm{~mL}$ of methanol/water (containing 5\% formic acid; 7:3, v/v). After $1 \mathrm{~h}$ on the ultrasonic bath, the resulting mixture was centrifuged at $4500 \mathrm{rpm}$. The solution was concentrated under vacuum at $40{ }^{\circ} \mathrm{C}$ until methanol was eliminated. To the residual aqueous extract, $0.1 \%$ solution of hydrochloric acid was added to a final volume of $10 \mathrm{~mL}$. This solution was further purified through a SPE column, which was previously conditioned with $3 \mathrm{~mL}$ of methanol and $9 \mathrm{~mL}$ of ultra-pure water. After applying to the SPE column, the sample was washed with $6 \mathrm{~mL}$ of ultra-pure water to remove all residual sugars and other polar compounds. The aqueous fraction was used for the determination of sugars using 
HPAEC-PAD system. The phenolic fraction was eluted from a cartridge with a solution of $1.5 \mathrm{~mL}$ of acidified methanol $\left(0.1 \% \mathrm{HCl}\right.$ solution). The resulting methanol solutions were stored at $-20{ }^{\circ} \mathrm{C}$ until analyzed. The extracts were filtered through a $0.45 \mu$ m nylon membrane filter prior to UHPLC-DAD MS/MS analysis.

\subsection{Analysis of Carbohydrate Content}

For the quantification of sugars and sugar alcohols the HPAEC-PAD system was used. Carbohydrates were analyzed in pollen samples on a Carbo PacPA10 pellicular anion-exchange column $\left(4 \times 250 \mathrm{~mm}\right.$; Dionex, Sunnyvale, CA, USA) at $30^{\circ} \mathrm{C}$. Each sample $(25 \mu \mathrm{L})$ was injected with an ICS AS-DV 50 autosampler (Dionex, Sunnyvale, CA, USA). Carbohydrates were eluted with a flow rate set to $0.7 \mathrm{~mL} / \mathrm{min}$, in gradient prepared from $600 \mathrm{mM}$ sodium hydroxide (eluent A), $500 \mathrm{mM}$ sodium acetate (eluent $\mathrm{B}$ ), and ultrapure water (eluent $\mathrm{C}$ ). The gradient program was as follows: 0.0-20.0 min, 15\% A; 20.1-30.0 min, 20\% A; 0.0-5.0 min, 0\% B; 5.1-12.0 min, 2\% B; 12.1-20.0 min, 4\% B; and 20.1-30.0 $\mathrm{min}, 20 \% \mathrm{~B}$. The calibration of carbohydrates was performed with standard solutions of sugars and sugar alcohols. Table 1 provides data on limit of detection (LOD), limit of quantification (LOQ), and recovery ( $\mathrm{R}, \%)$.

Table 1. Validation parameters: Retention time $\left(t_{\mathrm{R}}\right)$, limit of detection (LOD), limit of quantification (LOQ), and recovery $(R, \%)$.

\begin{tabular}{ccccc}
\hline Name & $\boldsymbol{t}_{\mathbf{R}}(\mathbf{m i n})$ & $\mathbf{L O D} \times \mathbf{1 0}^{-\mathbf{3}}(\boldsymbol{\mu g} / \mathbf{m L})$ & $\mathbf{L O Q} \times \mathbf{1 0}^{-\mathbf{3}}(\boldsymbol{\mu g} / \mathbf{m L})$ & $\boldsymbol{R}(\mathbf{\%})$ \\
\hline Sorbitol & 2.76 & 0.19 & 0.57 & 102 \\
Trehalose & 3.55 & 0.25 & 0.76 & 109 \\
Arabinose & 4.85 & 0.19 & 0.58 & 98 \\
Glucose & 5.55 & 0.06 & 0.17 & 103 \\
Fructose & 6.41 & 0.08 & 0.24 & 104 \\
Isomaltose & 8.70 & 0.12 & 0.35 & 97 \\
Sucrose & 9.20 & 0.09 & 0.26 & 99 \\
Turanose & 14.90 & 0.05 & 0.16 & 105 \\
Maltose & 17.89 & 0.10 & 0.30 & 101 \\
Maltotriose & 23.12 & 0.15 & 0.48 & 95 \\
\hline
\end{tabular}

\subsection{Determination of Individual Polyphenols}

For the quantification of phenolic compounds the UHPLC-DAD MS/MS system was used. Elution was done on $40{ }^{\circ} \mathrm{C}$, using mobile phase water $+0.1 \%$ acetic acid (A) and acetonitrile (B) on Syncronis C18 column, in the following concentration gradient: 5\% B, $2.0 \mathrm{~min}$; 5-95\% B, 2.0-12.0 min; 95-5\% B, 12.0-12.2 $\mathrm{min}$; and $5 \% \mathrm{~B}$ to $15 \mathrm{~min}$. The mobile phase flow was set to $0.3 \mathrm{~mL} / \mathrm{min}$, and wavelengths were 254 and $280 \mathrm{~nm}$. Injection volume was $5 \mu \mathrm{L}$.

A mass spectrometer was equipped with a heated electrospray ionization source with the vaporizer temperature kept at $200{ }^{\circ} \mathrm{C}$, with a spray voltage of $5 \mathrm{kV}$ and capillary temperature of $300{ }^{\circ} \mathrm{C}$. The mass spectrometry data were acquired in the negative ion mode, in the $\mathrm{m} / \mathrm{z}$ range from 100 to 1000 . Multiple mass spectrometric scanning modes, including full scanning (FS), and product ion scanning (PIS), were conducted for the qualitative analysis of the targeted compounds. The collision-induced fragmentation experiments were performed using argon as the collision gas, and the collision energy was varied depending on the compound. For the quantitative analysis of phenolic compounds the time-selected reaction monitoring (tSRM) experiments were performed for each standard compound. The molecular ions and the two most intense fragments from the $\mathrm{MS}^{2}$ spectrum were previously defined as dominant in the PIS experiments (Table 2). Table 2 also provides the LOD, LOQ, and correlation coefficient.

Xcalibur software (version 2.2; Thermo Fisher Scientific, Bremen, Germany) was used to control the instrument [44]. Polyphenols were quantified in pollen by comparing with commercial standards. Only the MS/MS peak areas were used for quantification and calibration curves for each standard were 
obtained. The total content of each compound was calculated by comparing the peak area with the peak area of the corresponding standard, and were expressed as $\mathrm{mg} / \mathrm{kg}$.

Table 2. List of quantified phenolics in in negative ion mode: Parent ion $(\mathrm{m} / \mathrm{z})$, product ions $(\mathrm{m} / \mathrm{z})$ with specified collision energy $(\mathrm{CE}, \mathrm{eV})$, mean expected retention time $\left(t_{\mathrm{R}}, \mathrm{min}\right)$, limit of detection (LOD, $\mathrm{mg} / \mathrm{L})$ and quantification (LOQ, $\mathrm{mg} / \mathrm{L})$, and correlation coefficient $\left(R^{2}\right)$.

\begin{tabular}{|c|c|c|c|c|c|c|c|}
\hline No & Compound & Parent Ion, $m / z$ & Product Ion, $m / z(\mathrm{CE}, \mathrm{eV})$ & $t_{\mathrm{R}}, \min$ & LOD & LOQ & $R^{2}$ \\
\hline \multicolumn{8}{|c|}{ Benzoic Acid Derivatives } \\
\hline 1 & Protocatechuic acid & 153.013 & 108.09 (23); 109.10 (14) & 4.44 & 0.10 & 0.34 & 0.9980 \\
\hline 2 & $p$-Hydroxybenzoic acid & 137.057 & 93.19 (19); $108.33(22)$ & 4.68 & 0.14 & 0.48 & 0.9934 \\
\hline 3 & Vanillic acid & 167.034 & $153.00(15) ; 108.00(21)$ & 5.67 & 0.02 & 0.08 & 0.9957 \\
\hline 4 & Syringic acid & 197.046 & $153.02(16) ; 182.02(21)$ & 6.07 & 0.04 & 0.13 & 0.9968 \\
\hline 5 & Ellagic acid & 300.98 & $284.00(32) ; 300.04(30)$ & 6.76 & 0.11 & 0.37 & 0.9938 \\
\hline \multicolumn{8}{|c|}{ Cinnamic Acid Derivatives } \\
\hline 6 & Chlorogenic acid & 353.103 & $191.28(25)$ & 5.33 & 0.08 & 0.27 & 0.9980 \\
\hline 7 & Caffeic acid & 179.004 & $134.00(13) ; 135.00(16)$ & 5.82 & 0.11 & 0.38 & 0.9951 \\
\hline 8 & $p$-Coumaric acid & 163.031 & 93.12 (39); 119.09 (16) & 6.67 & 0.12 & 0.41 & 0.9947 \\
\hline 9 & Ferulic acid & 193.057 & $134.00(18) ; 178.00$ (15) & 6.93 & 0.15 & 0.50 & 0.9933 \\
\hline 10 & Sinapic acid & 223.082 & $149.21(36)$ & 6.95 & 0.08 & 0.26 & 0.9984 \\
\hline 11 & Cinnamic acid & 147.050 & $103.00(10) ; 129.00(10)$ & 8.73 & 0.07 & 0.22 & 0.9991 \\
\hline \multicolumn{8}{|c|}{ Flavonoid Glycosides } \\
\hline 12 & Rutin & 609.197 & 299.98 (42); $301.20(32)$ & 6.42 & 0.09 & 0.31 & 0.9976 \\
\hline 13 & Hyperoside & 463.100 & 300.00 (30); $271.00(43)$ & 6.67 & 0.10 & 0.34 & 0.9976 \\
\hline 14 & Cynaroside & 447.090 & $285.00(30)$ & 6.91 & 0.12 & 0.40 & 0.9975 \\
\hline 15 & Apiin & 563.140 & $465.00(25) ; 269.00(46)$ & 6.97 & 0.11 & 0.38 & 0.9956 \\
\hline 16 & Naringin & 579.241 & $151.42(43) ; 217.26(33)$ & 7.01 & 0.16 & 0.53 & 0.9937 \\
\hline 17 & Astragalin & 447.090 & 284.00 & 7.03 & 0.14 & 0.46 & 0.9975 \\
\hline \multicolumn{8}{|c|}{ Flavonoid Aglycones } \\
\hline 18 & Catechin & 289.094 & $203.00(23) ; 245.03(31)$ & 5.41 & 0.14 & 0.45 & 0.9953 \\
\hline 19 & Luteolin & 285.035 & 133.05 (30); $150.95(24)$ & 8.45 & 0.10 & 0.32 & 0.9958 \\
\hline 20 & Apigenin & 269.032 & 117.24 (43); $149.00(24)$ & 9.12 & 0.11 & 0.36 & 0.9981 \\
\hline 21 & Naringenin & 271.036 & 119.10 (25); 151.07 (19) & 9.22 & 0.09 & 0.28 & 09974 \\
\hline 22 & Kaempferol & 285.074 & $211.00(32) ; 227.00(32)$ & 9.39 & 0.04 & 0.13 & 0.9961 \\
\hline \multicolumn{8}{|c|}{ Other Phenolics } \\
\hline 23 & Aesculin & 339.080 & $133.09(44) ; 177.06(25)$ & 4.95 & 0.01 & 0.05 & 0.9999 \\
\hline 24 & Phlorizin & 435.149 & $273.16(20) ; 167.16(34)$ & 7.37 & 0.05 & 0.15 & 0.9978 \\
\hline 25 & Coniferyl aldehyde & 177.060 & 162.00 (17); 97.00 (14) & 7.70 & 0.03 & 0.08 & 0.9968 \\
\hline 26 & Aesculetin & 176.992 & $133.28(19) ; 105.25(20)$ & 7.71 & 0.10 & 0.34 & 0.9969 \\
\hline
\end{tabular}

\subsection{Statistical Analysis}

Data of all measurements presented in the tables are the mean of three replicates \pm standard deviation. Tukey's test was used to detect the significance of differences $(p \leq 0.05)$ between mean values. Statistical analyses were performed using the NCSS program (www.ncss.com) [44]. Principal component analysis was performed using the PLS_ToolBox software package for MATLAB (Version 7.12.0; (Eigenvector Research, Inc., Wenatchee, WA, USA) [44].

\section{Results and Discussion}

\subsection{Carbohydrate Profile}

The content of carbohydrates in 15 pollen samples is shown in Table 3 as a mean value for 2015 and 2016. Glucose was the most abundant sugar, followed by fructose, sucrose, and sugar alcohol sorbitol. According to the obtained average values of all analyzed saccharides, the sum of the glucose, fructose, and sucrose in investigated pollen samples was from 86.18 to $93.46 \%$ (cones VIII/1 and II/10, respectively). Based on the total content of the analyzed sugars and sugar alcohols, primarily genotypes 
$\mathrm{I} / 1(324.86 \mathrm{mg} / \mathrm{g})$, and XIII/1 $(283.65 \mathrm{mg} / \mathrm{g})$ had the largest amounts. The glucose/fructose ratios were also calculated, as presented in Table 3. The two monosaccharide concentrations had roughly equal amounts in clones III/9, IV/1, V/P, and X/2, which was expected since sucrose synthase and invertase digests sucrose to glucose and fructose [47]. Other pollen samples were characterized with ratios above 1.0, even one pollen sample (VII/2P) had the G/F ratio 1.8 (Table 3). The content of dominant sugar components, glucose, fructose, and sucrose varied significantly among investigated clones, indicating high variability. No matter that it is already proven that fructose and glucose concentrations in pollen vary according to the botanical origin [48], in this study their level was genetically dependent.

Glucose was the most abundant sugar and it was the largest in clone I/1 (136.71 mg/g). Clone IX/1 stored a high concentration of glucose $(132.49 \mathrm{mg} / \mathrm{g})$. The contents of fructose and sucrose varied in the range from 56.72 (VII/2P) to $92.73 \mathrm{mg} / \mathrm{g}$ (I/1), and from 31.92 (IX/1) to $75.11 \mathrm{mg} / \mathrm{g}$ (II/2), respectively. Besides being important for pollen germination in reproductive process, sucrose in pollen is crucial for bee-learning processes and memory formation in foraging choice [49].

For minor sugar components, such as trehalose, arabinose, isomaltose, turanose, maltose, and maltotriose, some variations were found among clones. For trehalose a range of concentrations was measured from 0.93 (in II/2) to $5.31 \mathrm{mg} / \mathrm{g}$ (in VIII/1). Trehalose is a product of the activity of trehalose-6-phopahet synthase as a response to hydration and desiccation. The fact that up to five times more trehalose was detected in several genotypes potentially can be associated with prolonged drought of those genotypes [50]. Interestingly, pollen sample VIII/1 was reported to have the highest content of maltotriose $(0.54 \mathrm{mg} / \mathrm{g})$, but the lowest concentrations of arabinose $(0.17 \mathrm{mg} / \mathrm{g})$ and isomaltose $(0.48 \mathrm{mg} / \mathrm{g})$. Further, sorbitol was found in the range from 7.12 (VII/2P) to $22.38 \mathrm{mg} / \mathrm{g}$ (VIII/1), and it was almost as large as in the sample IX/P.

\subsection{Phenolic Profile}

Phenolic compounds, which are very variable in pollen grains, are the most important bioactive substances in pollen because they provide antioxidant activity, antimicrobial capability, and are responsible for the color and bitter taste of the grain [27,51]. According to Negri et al., the main constituents of pollen phenolics are flavonoid glycosides [52]. In this study, twenty-six different phenolic compounds were quantified using the available commercial standards and the results are presented in Table 4. Due to the easier explanation, phenolics were divided into five structurally different groups: (1) Benzoic acid derivatives (five compounds), (2) cinnamic acid derivatives (six compounds), (3) flavonoid glycoside (six compounds), (4) flavonoid aglycones (five compounds), and (5) other phenolics (five compounds). The sour cherry clone with the highest content of determined phenolics was IV/8 (445.57 mg/kg), while clone V/P had the lowest content of phenolic compounds $(89.98 \mathrm{mg} / \mathrm{kg})$. 
Table 3. The average (2015 and 2016) contents of carbohydrates (mg/g), in pollen of 15 'Oblačinska' sour cherry clones.

\begin{tabular}{|c|c|c|c|c|c|c|c|c|c|c|c|c|c|c|c|}
\hline Carbohydrates/Clones & $\mathrm{I} / \mathbf{1}$ & $\mathrm{II} / 2$ & $\mathrm{II} / \mathbf{1 0}$ & III/9 & IV/1 & IV/8 & $\mathbf{V} / \mathbf{P}$ & $\mathrm{VII} / 2 \mathrm{P}$ & VIII/1 & $\mathrm{IX} / 1$ & $\mathrm{IX} / \mathbf{P}$ & $\mathrm{X} / 2$ & $\mathrm{XIII} / 1$ & $\mathrm{XIV} / 3$ & $\mathrm{XIV} / 5$ \\
\hline Sorbitol & $16.00^{\mathrm{e}}$ & $14.03^{\mathrm{d}}$ & $9.87^{b}$ & $11.28^{c}$ & $7.22^{a}$ & $8.01^{\mathrm{a}}$ & $17.41^{\mathrm{f}}$ & $7.12^{\mathrm{a}}$ & $22.38^{h}$ & $16.68^{\mathrm{e}, \mathrm{f}}$ & $21.03^{g}$ & $14.96^{\mathrm{d}}$ & $14.83^{\mathrm{d}}$ & $17.30^{f}$ & $17.24^{\mathrm{f}}$ \\
\hline Trehalose & $4.03^{\mathrm{e}}$ & $0.93^{\mathrm{a}}$ & $1.58^{b}$ & $2.36^{\mathrm{c}}$ & $3.54 \mathrm{~d}^{\mathrm{e}}$ & $3.19^{\mathrm{c}, \mathrm{d}}$ & $2.98^{c}$ & $4.73^{f}$ & $5.31^{\mathrm{g}}$ & $2.50^{\mathrm{c}}$ & $1.84^{\mathrm{b}}$ & $2.36^{\mathrm{c}}$ & $1.52^{\mathrm{b}}$ & $4.23^{\mathrm{e}, \mathrm{f}}$ & $4.56^{\mathrm{f}}$ \\
\hline Arabinose & $0.35^{\mathrm{b}}$ & $0.48^{c}$ & $0.30^{\mathrm{b}}$ & $0.23^{\mathrm{a}, \mathrm{b}}$ & $0.46^{\mathrm{c}}$ & $0.20^{\mathrm{a}}$ & $0.64^{\mathrm{d}}$ & $0.49^{c}$ & $0.17^{\mathrm{a}}$ & $0.34^{\mathrm{b}}$ & $0.28^{b}$ & $0.18^{\mathrm{a}}$ & $0.38^{\mathrm{b}}$ & $0.74^{\mathrm{e}}$ & $0.49^{c}$ \\
\hline Glucose (G) & $136.71^{\mathrm{k}}$ & $89.77^{b}$ & $116.71^{\mathrm{h}}$ & $86.44^{\mathrm{a}}$ & $95.69^{\mathrm{d}}$ & $91.46^{c}$ & $95.44^{\mathrm{d}}$ & $102.38^{\mathrm{e}}$ & $107.47^{\mathrm{f}}$ & $132.49^{j}$ & $92.61^{c}$ & $85.83^{a}$ & $129.51^{\mathrm{i}}$ & $95.42^{d}$ & $110.68^{\mathrm{g}}$ \\
\hline Fructose (F) & $92.73^{j}$ & $68.57^{b}$ & $83.52^{f}, \mathrm{~g}$ & $85.04^{h}$ & $87.45^{\mathrm{i}}$ & $71.60^{c}$ & $91.69^{j}$ & $56.72^{a}$ & $74.70^{\mathrm{d}}$ & $82.17^{\mathrm{e}, \mathrm{f}}$ & $67.25^{b}$ & $81.31^{\mathrm{e}}$ & $86.96^{\mathrm{i}}$ & $82.46^{e, f}$ & $84.45^{\mathrm{g}, \mathrm{h}}$ \\
\hline Sucrose & $66.40^{j}$ & $75.11^{k}$ & $56.12 \mathrm{~g}$ & $73.97^{k}$ & $50.75^{f}$ & $59.38^{h}$ & $38.58^{b}$ & $63.84^{\mathrm{i}}$ & $38.64^{b}$ & $31.92^{\text {a }}$ & $36.68^{b}$ & $42.58^{c}$ & $41.83^{c}$ & $46.88^{\text {e }}$ & $44.78^{\mathrm{d}}$ \\
\hline Isomaltotriose & $0.91^{\mathrm{e}}$ & $1.16^{\mathrm{f}}$ & $0.49^{\mathrm{a}}$ & $0.78^{\mathrm{d}}$ & $0.67^{c}$ & $0.94^{\mathrm{e}}$ & $0.92 \mathrm{e}$ & $0.69^{c, d}$ & $0.48^{\mathrm{a}}$ & $1.34^{\mathrm{g}}$ & $0.65^{c}$ & $0.56^{\mathrm{b}}$ & $1.92^{\mathrm{i}}$ & $1.20^{\mathrm{f}}$ & $1.81^{\mathrm{h}}$ \\
\hline Turanose & $0.38^{c}$ & $0.39^{c, d}$ & $0.16^{\mathrm{a}}$ & $0.44^{\mathrm{d}}$ & $0.60^{f}$ & $0.85^{\mathrm{g}}$ & $0.27^{b}$ & $0.28^{\mathrm{b}}$ & $0.47^{\mathrm{d}, \mathrm{e}}$ & $0.35^{b, c}$ & $0.60^{f}$ & $0.36^{\mathrm{b}, \mathrm{c}}$ & $0.54^{\mathrm{e}, \mathrm{f}}$ & $0.38^{\mathrm{c}}$ & $0.55^{\mathrm{e}, \mathrm{f}}$ \\
\hline Maltose & $7.17^{\mathrm{e}}$ & $8.60^{f}$ & $5.27^{\mathrm{c}}$ & $7.48^{\mathrm{e}}$ & $6.27^{\mathrm{d}}$ & $6.54^{\mathrm{d}}$ & $5.64^{\mathrm{c}}$ & $2.31^{\mathrm{a}}$ & $6.05^{c}$ & $3.84^{\mathrm{b}}$ & $5.61^{\mathrm{c}}$ & $4.23^{b}$ & $5.94^{c}$ & $4.36^{\mathrm{b}}$ & $4.02^{b}$ \\
\hline Maltotriose & $0.18^{a}$ & $0.38^{\mathrm{c}}$ & $0.26^{b}$ & $0.47^{\mathrm{d}}$ & $0.24^{b}$ & $0.18^{a}$ & $0.32^{c}$ & $0.19^{\mathrm{a}}$ & $0.54^{\mathrm{e}}$ & $0.30^{b, c}$ & $0.20^{\mathrm{a}}$ & $0.40^{\mathrm{c}, \mathrm{d}}$ & $0.22^{a, b}$ & $0.28^{b, c}$ & $0.44^{\mathrm{d}}$ \\
\hline $\mathrm{G} / \mathrm{F}$ ratio & 1.47 & 1.31 & 1.40 & 1.02 & 1.09 & 1.28 & 1.04 & 1.81 & 1.44 & 1.61 & 1.38 & 1.06 & 1.49 & 1.16 & 1.31 \\
\hline Total & 324.86 & 259.42 & 274.28 & 268.49 & 252.89 & 242.35 & 253.89 & 238.75 & 256.21 & 271.93 & 226.75 & 232.77 & 283.65 & 253.25 & 269.02 \\
\hline
\end{tabular}


$p$-Hydroxybenzoic, vanillic, and syringic acids were found in all fifteen investigated pollen samples of the sour cherry clones. Vanillic acid was found to be the dominant with concentration up to $10 \mathrm{mg} / \mathrm{kg}$ in three clones (I/1, VIII/1, and XIII/1). Bonvehí el al. also found vanillic acid as a very important constituent of pollen grains that is responsible for antioxidant activity [53]. Protocatechuic acid and ellagic acid were quantified in several samples mainly at low concentrations. However, the concentration of ellagic acid in clone VIII/1 $(1.75 \mathrm{mg} / \mathrm{kg})$ was significantly higher when compared with the other clones.

The results of the LC/MS analysis have shown that cinnamic acid derivatives were abundant in sour cherry pollen extracts. All derivatives, except sinapic acid and cinnamic acid, were found in considerable quantity. According to Almaraz-Abarca et al. the most common phenolic acids in pollen are chlorogenic, ferulic, cinnamic, and caffeic acids [4]. Chlorogenic acid was found to be dominant with a concentration up to $50 \mathrm{mg} / \mathrm{kg}$ in four clones (III/9, VIII $/ 1, \mathrm{XIII} / 1$, and XIV/3). The compounds, caffeic acid and $p$-coumaric acid, were found to be the most abundant in clones IV/8 $(15.95 \mathrm{mg} / \mathrm{kg}$ and $51.20 \mathrm{mg} / \mathrm{kg}$, respectively) and VIII/1 (15.35 mg/kg and $53.99 \mathrm{mg} / \mathrm{kg}$, respectively). Some studies reveled that chlorogenic acid has positive effects on Alzheimer's disease, obesity, and blood pressure [54]. Caffeic acid has a strong antioxidant capacity by eliminating oxygen free radicals, which in combination with chlorogenic acid has an even more powerful effect. Besides it protects $\alpha$-tocopherol in low-density lipoprotein and it is a promising photoprotective agent [55]. $p$-Coumaric acid was also proved to have high antioxidative properties and protect humans from various kinds of cancer and cardiovascular diseases [56]. Ferulic acid and sinapic acid were quantified in the highest concentrations in clone IV/8 ( $56.70 \mathrm{mg} / \mathrm{kg}$ and $5.21 \mathrm{mg} / \mathrm{kg}$, respectively).

Rutin (quercetin 3-O-rutinoside) was the predominant compound from the group of flavonoid glycosides and the most abundant phenolic compound found in sour cherry pollen in this study. The lowest amount of rutin was found in clone V/P $(50.28 \mathrm{mg} / \mathrm{kg})$ and the highest amount was found in clone III/9 $(181.12 \mathrm{mg} / \mathrm{kg})$. This indicates high biological and nutritional quality of studied pollen due to its high antioxidant activity [57]. Generally, rutin was demonstrated to have a neuroprotective effect, sedative, anticonvulsant, analgesic, and antiarthritic activities, antidiabetic and antiosteoporotic effect, and to improve the cardiovascular, respiratory, reproductive, and gastrointestinal system [58].

Among the other investigated flavonoid glycosides, hyperoside-quercetin 3-O-galactoside $(18.10 \mathrm{mg} / \mathrm{kg}$ and clone III/9) and astragalin-kaempferol 3-O-glucoside (31.17 mg/kg and clones IV/8) were found at significant concentrations compared to the other compounds in this group.

From the group of flavonoid aglycones, catechin was found in slightly higher concentration, ranging from 3.11 (clone XIV/5) to $8.87 \mathrm{mg} / \mathrm{kg}$ (clone III/9), but the most abundant was kaempferol with a concentration of $27.01 \mathrm{mg} / \mathrm{kg}$ in clone IV/8. Generally one of the main flavonols in bee pollen is kaempferol [59]. Other flavonoid aglycones were quantified in very low amounts such as luteolin, apigenin, and naringenin. The results obtained in the work of Al-Samarrai et al. indicated that date palm pollen has some level of naringin $(64.574 \mathrm{mg} / \mathrm{kg})$, and apigenin $(109.117 \mathrm{mg} / \mathrm{kg})$ too [60].

The other phenolic compound, coumarin aesculin was found in large concentrations in several clones, with the highest value of $29.25 \mathrm{mg} / \mathrm{kg}$ in clone VIII/1. In the same clone, the highest concentration of aesculetin, also coumarin derivate, was found at a concentration of $0.98 \mathrm{mg} / \mathrm{kg}$. According to Tattini et al. the role of aesculin and aesculetin is in photoprotection, and these phenolic compounds can have the same role in pollen grains [61]. 
Table 4. The average (2015 and 2016) contents of phenolic compounds (mg/kg), in pollen of 15 'Oblačinska' sour cherry clones.

\begin{tabular}{|c|c|c|c|c|c|c|c|c|c|c|c|c|c|c|c|c|}
\hline No & $\begin{array}{c}\text { Phenolic } \\
\text { Compounds/Clones }\end{array}$ & $\mathrm{I} / \mathbf{1}$ & $\mathrm{II} / 2$ & $\mathrm{II} / 10$ & III/9 & $\mathrm{IV} / 1$ & IV/8 & $\mathbf{V} / \mathbf{P}$ & $\mathrm{VII} / 2 \mathrm{P}$ & VIII/1 & $\mathrm{IX} / \mathbf{1}$ & $\mathrm{IX} / \mathrm{P}$ & $X / 2$ & XIII/1 & $\mathrm{XIV} / 3$ & $\mathrm{XIV} / 5$ \\
\hline \multicolumn{17}{|c|}{ Benzoic Acid Derivatives } \\
\hline 1 & Protocatechuic acid & $0.42^{\mathrm{d}}$ & - & - & - & - & $0.10^{\mathrm{b}}$ & - & $0.11^{\mathrm{b}}$ & $0.54^{\mathrm{e}}$ & $0.04^{\mathrm{a}}$ & $0.12^{b}$ & $0.08^{a, b}$ & $0.34^{\mathrm{c}}$ & $0.64^{\mathrm{f}}$ & $0.04^{\mathrm{a}}$ \\
\hline 2 & $p$-Hydroxybenzoic acid & $4.45^{\mathrm{e}}$ & $1.70^{\mathrm{b}}$ & $2.91^{\mathrm{c}}$ & $3.62^{\mathrm{d}}$ & $2.37^{\mathrm{c}}$ & $5.57^{\mathrm{f}}$ & $0.75^{\mathrm{a}}$ & $3.63^{\mathrm{d}}$ & $7.80 \mathrm{~g}$ & $2.46^{\mathrm{c}}$ & $3.62^{\mathrm{d}}$ & $2.86^{\mathrm{c}}$ & $7.85^{\mathrm{g}}$ & $5.50^{\mathrm{f}}$ & $3.81 \mathrm{~d}, \mathrm{e}$ \\
\hline 3 & Vanillic acid & $10.68^{g}$ & $1.52^{b}$ & $1.75^{b}$ & $2.16^{\mathrm{c}}$ & $2.58^{c}$ & $3.47^{\mathrm{d}}$ & $0.57^{\mathrm{a}}$ & $4.54^{\mathrm{e}}$ & $10.68^{\mathrm{g}}$ & $1.35^{\mathrm{b}}$ & $2.16^{\mathrm{c}}$ & $1.39^{b}$ & $10.92^{g}$ & $7.74^{\mathrm{f}}$ & $2.82^{c}$ \\
\hline 4 & Syringic acid & $0.65^{\mathrm{b}}$ & $0.58^{\mathrm{b}}$ & $0.61^{b}$ & $0.95^{\mathrm{e}}$ & $0.64^{\mathrm{b}}$ & $1.22^{\mathrm{f}}$ & $0.20^{\mathrm{a}}$ & $0.55^{\mathrm{b}}$ & $0.65^{\mathrm{b}}$ & $0.54^{\mathrm{b}}$ & $0.73^{c}$ & $0.80^{\mathrm{d}}$ & $0.72^{c}$ & $0.72^{\mathrm{c}}$ & $0.59^{b}$ \\
\hline \multirow[t]{3}{*}{5} & Ellagic acid & - & $0.37^{\mathrm{d}}$ & - & - & - & - & $0.02^{\mathrm{a}}$ & $0.04^{\mathrm{a}}$ & $1.75^{\mathrm{e}}$ & $0.17^{b}$ & $0.08^{\mathrm{a}}$ & $0.28^{c}$ & - & $0.06^{\mathrm{a}}$ & - \\
\hline & Total & 16.20 & 4.17 & 5.27 & 6.73 & 5.59 & 10.36 & 1.54 & 8.87 & 21.42 & 4.56 & 6.71 & 5.41 & 19.83 & 14.66 & 7.26 \\
\hline & \multicolumn{16}{|c|}{ Cinnamic Acid Derivatives } \\
\hline 6 & Chlorogenic acid & $43.70^{\mathrm{f}}$ & $29.28^{c}$ & $23.64^{\mathrm{b}}$ & $59.93^{j}$ & $34.24^{\mathrm{d}}$ & $42.57^{f}$ & $7.27^{\mathrm{a}}$ & $37.23^{\mathrm{e}}$ & $58.93^{j}$ & $33.21^{\mathrm{d}}$ & $38.46^{\mathrm{e}}$ & $47.66^{\mathrm{g}}$ & $53.33^{\mathrm{h}}$ & $56.85^{i}$ & $24.92^{b}$ \\
\hline 7 & Caffeic acid & $5.51^{\mathrm{c}}$ & $1.99^{\mathrm{a}}$ & $3.56^{\mathrm{b}}$ & $5.03^{c}$ & $3.18^{\mathrm{b}}$ & $15.95^{f}$ & $1.36^{\mathrm{a}}$ & $3.78^{\mathrm{b}}$ & $15.35^{f}$ & $2.99^{b}$ & $3.98 b^{c}$ & $4.23^{c}$ & $6.17^{\mathrm{d}}$ & $12.94 \mathrm{e}$ & $3.46^{\mathrm{b}}$ \\
\hline 8 & $p$-Coumaric acid & $29.89^{e}$ & $10.52^{b}$ & $19.84^{c}$ & $26.54^{d}$ & $18.19^{c}$ & $51.20^{\mathrm{h}}$ & $4.82^{\mathrm{a}}$ & $24.58^{d}$ & $53.99^{\mathrm{h}}$ & $18.60^{c}$ & $23.49^{d}$ & $18.45^{c}$ & $42.94 \mathrm{~g}$ & $39.03^{f}$ & $24.29^{\mathrm{d}}$ \\
\hline 9 & Ferulic acid & $35.22 \mathrm{~g}$ & $10.68^{b}$ & $19.01^{\mathrm{d}}$ & $24.83^{\mathrm{f}}$ & $16.81^{\mathrm{c}}$ & $56.70^{\mathrm{i}}$ & $7.11^{\mathrm{a}}$ & $21.99^{\mathrm{e}}$ & $43.93^{h}$ & $16.87^{c}$ & $18.71^{\mathrm{d}}$ & $21.68^{\mathrm{e}}$ & $43.60^{\mathrm{h}}$ & $42.46^{\mathrm{h}}$ & $20.76^{\mathrm{d}, \mathrm{e}}$ \\
\hline 10 & Sinapic acid & $1.79 \mathrm{~d}, \mathrm{e}$ & - & - & $1.59^{c, d}$ & - & $5.21^{\mathrm{f}}$ & $0.22^{\mathrm{a}}$ & - & - & - & - & $0.83^{\mathrm{b}}$ & $1.42^{\mathrm{c}}$ & $2.28^{\mathrm{e}}$ & - \\
\hline \multirow[t]{3}{*}{11} & Cinnamic acid & $2.44^{\mathrm{g}}$ & $0.59^{b}$ & $0.90^{\mathrm{c}}$ & $1.04^{\mathrm{c}}$ & $1.22^{\mathrm{d}}$ & $1.61^{\mathrm{e}}$ & $0.19^{\mathrm{a}}$ & $1.18^{\mathrm{d}}$ & $2.75^{\mathrm{h}}$ & $0.99^{\mathrm{c}}$ & $1.00^{\mathrm{c}}$ & $1.00^{\mathrm{c}}$ & $1.95^{\mathrm{f}}$ & $1.54^{\mathrm{e}}$ & $1.16^{\mathrm{d}}$ \\
\hline & Total & 118.55 & 53.06 & 66.95 & 118.96 & 73.64 & 173.24 & 20.97 & 88.76 & 174.95 & 72.66 & 81.66 & 93.85 & 149.41 & 155.10 & 74.59 \\
\hline & \multicolumn{16}{|c|}{ Flavonoid Glycosides } \\
\hline 12 & Rutin & $92.96^{b}$ & $93.51^{\mathrm{b}}$ & $118.96^{\mathrm{e}}$ & $181.12^{\mathrm{i}}$ & $113.01^{d}$ & $157.95^{\mathrm{h}}$ & $50.28^{a}$ & $114.38^{\mathrm{d}}$ & $112.89^{\mathrm{d}}$ & $106.34^{c}$ & $117.42^{\mathrm{e}}$ & $139.47^{\mathrm{f}}$ & $119.42^{\mathrm{e}}$ & $144.43^{\mathrm{g}}$ & $107.03^{c}$ \\
\hline 13 & Hyperoside & $9.68^{b}$ & $9.44^{\mathrm{b}}$ & $11.07^{\mathrm{c}}$ & $18.10^{\mathrm{d}}$ & $11.08^{c}$ & $17.85^{\mathrm{b}}$ & $4.82^{\mathrm{a}}$ & $12.07^{c}$ & $11.05^{\mathrm{c}}$ & $10.44^{\mathrm{c}}$ & $12.15^{\mathrm{c}, \mathrm{d}}$ & $13.31^{\mathrm{d}}$ & $11.66^{c}$ & $13.91^{\mathrm{d}}$ & $11.03^{\mathrm{c}}$ \\
\hline 14 & Cynaroside & $6.14^{\mathrm{f}}$ & $0.34^{\mathrm{a}}$ & - & $1.15^{\mathrm{c}}$ & $0.76^{a, b}$ & $5.22 \mathrm{e}$ & - & $0.91^{\mathrm{b}}$ & - & $2.41^{\mathrm{d}}$ & - & - & $5.83^{\mathrm{e}, \mathrm{f}}$ & $2.58^{\mathrm{d}}$ & $0.91^{\mathrm{b}}$ \\
\hline 15 & Apiin & $0.08^{c}$ & $0.01^{\mathrm{a}}$ & $0.04^{b}$ & $0.04^{b}$ & - & $0.09^{c}$ & - & $0.05^{\mathrm{b}}$ & $0.16^{\mathrm{d}}$ & $0.04^{\mathrm{b}}$ & $0.05^{\mathrm{b}}$ & $0.03^{a, b}$ & - & $0.06^{\mathrm{b}}$ & $0.05^{\mathrm{b}}$ \\
\hline 16 & Naringin & $0.22^{c}$ & $0.08^{\mathrm{a}}$ & $0.14^{\mathrm{b}}$ & $0.17^{\mathrm{b}}$ & $0.13^{\mathrm{b}}$ & $0.28^{\mathrm{d}}$ & $0.05^{\mathrm{a}}$ & $0.15^{\mathrm{b}}$ & $0.34^{\mathrm{e}}$ & $0.14^{\mathrm{b}}$ & $0.16^{\mathrm{b}}$ & $0.17^{\mathrm{b}}$ & $0.24^{\mathrm{c}}$ & $0.21^{\mathrm{c}}$ & $0.15^{\mathrm{b}}$ \\
\hline \multirow[t]{3}{*}{17} & Astragalin & $15.04^{b}$ & $14.05^{b}$ & $18.32^{d}$ & $22.82^{\mathrm{e}}$ & $14.17^{b}$ & $31.17^{\mathrm{f}}$ & $7.40^{\mathrm{a}}$ & $15.38^{b}$ & $16.90^{\mathrm{b}}$ & $14.75^{b}$ & $16.98^{b}$ & $\underset{\mathrm{d}, \mathrm{e}}{20.42}$ & $16.86^{b}$ & $19.10^{\mathrm{d}}$ & $14.84^{b}$ \\
\hline & Total & 124.12 & 117.43 & 148.53 & 223.40 & 139.15 & 212.56 & 62.55 & 142.94 & 141.34 & 134.12 & 146.76 & 173.40 & 154.01 & 180.29 & 134.01 \\
\hline & \multicolumn{16}{|c|}{ Flavonoid Aglycones } \\
\hline 18 & Catechin & $5.07 \mathrm{bc}$ & $4.98 \mathrm{bc}$ & $4.47^{\mathrm{b}}$ & $8.87^{\mathrm{d}}$ & $4.63^{b}$ & $5.99^{c}$ & - & $5.62^{c}$ & $5.07 \mathrm{bc}$ & $4.57^{\mathrm{b}}$ & $4.90^{b c}$ & $5.58^{\mathrm{c}}$ & $5.20 \mathrm{bc}$ & $5.21 \mathrm{bc}$ & $3.11^{\mathrm{a}}$ \\
\hline 19 & Luteolin & $0.26^{\mathrm{b}}$ & $0.35^{\mathrm{d}}$ & $0.40^{\mathrm{e}}$ & $0.44^{\mathrm{e}}$ & - & $0.31^{\mathrm{c}}$ & $0.20^{\mathrm{a}}$ & $0.34^{\mathrm{d}}$ & - & $0.30^{\mathrm{c}}$ & - & $0.43^{\mathrm{e}}$ & $0.40^{\mathrm{e}}$ & - & $0.32^{c}$ \\
\hline 20 & Apigenin & $0.08^{\mathrm{a}}$ & $0.10^{\mathrm{b}}$ & $0.11^{\mathrm{b}}$ & $0.17^{\mathrm{d}}$ & $0.11^{\mathrm{b}}$ & $0.17^{\mathrm{d}}$ & $0.07^{\mathrm{a}}$ & $0.18^{\mathrm{d}}$ & $0.16^{\mathrm{cd}}$ & $0.12^{b}$ & $0.07^{\mathrm{a}}$ & $0.11^{b}$ & $0.15^{c}$ & $0.15^{c}$ & $0.17^{\mathrm{d}}$ \\
\hline 21 & Naringenin & $0.07^{\mathrm{b}}$ & $0.13^{\mathrm{d}}$ & $0.12^{\mathrm{d}}$ & $0.18^{\text {ef }}$ & $0.10^{c}$ & $0.18^{\text {ef }}$ & $0.16^{\mathrm{de}}$ & $0.21^{\mathrm{f}}$ & $0.13^{d}$ & $0.12^{\mathrm{d}}$ & $0.04^{\mathrm{a}}$ & $0.13^{\mathrm{d}}$ & $0.13^{\mathrm{d}}$ & 0.15 de & $0.10^{\mathrm{c}}$ \\
\hline \multirow[t]{2}{*}{22} & Kaempferol & $0.97^{\mathrm{b}}$ & $0.95^{\mathrm{b}}$ & $1.53 \mathrm{~g}$ & $1.59 \mathrm{~g}$ & $1.16^{b c}$ & $27.01^{\mathrm{h}}$ & $0.68^{a}$ & $1.09^{b c}$ & $1.24^{\mathrm{d}}$ & $0.97^{b}$ & $1.18^{\mathrm{c}}$ & $1.32 \mathrm{e}$ & $1.18^{\mathrm{c}}$ & $1.31^{\mathrm{e}}$ & $1.38^{\mathrm{f}}$ \\
\hline & Total & 6.45 & 6.51 & 6.63 & 11.25 & 6.00 & 33.66 & 1.11 & 7.44 & 6.60 & 6.08 & 6.19 & 7.57 & 7.06 & 6.82 & 4.76 \\
\hline
\end{tabular}


Table 4. Cont.

\begin{tabular}{|c|c|c|c|c|c|c|c|c|c|c|c|c|c|c|c|c|}
\hline No & $\begin{array}{c}\text { Phenolic } \\
\text { Compounds/Clones }\end{array}$ & $\mathrm{I} / \mathbf{1}$ & $\mathrm{II} / 2$ & $\mathrm{II} / 10$ & III/9 & IV/1 & IV/8 & $\mathrm{V} / \mathrm{P}$ & $\mathrm{VII} / 2 \mathrm{P}$ & VIII/1 & $\mathrm{IX} / 1$ & $\mathrm{IX} / \mathrm{P}$ & $X / 2$ & $\mathrm{XIII} / \mathbf{1}$ & $\mathrm{XIV} / 3$ & $\mathrm{XIV} / 5$ \\
\hline \multicolumn{17}{|c|}{ Other Phenolics } \\
\hline 23 & Aesculin & $9.53^{c}$ & $7.61^{b}$ & $9.74^{c}$ & $12.61^{\mathrm{d}}$ & $9.93^{c}$ & $13.45^{\mathrm{d}}$ & $3.43^{\mathrm{a}}$ & $11.31^{\mathrm{d}}$ & $29.25^{f}$ & $9.31^{\mathrm{c}}$ & $10.52^{c}$ & $10.17^{c}$ & $12.50^{\mathrm{d}}$ & $17.14^{\mathrm{e}}$ & $9.38^{c}$ \\
\hline 24 & Phlorizin & $0.51^{\mathrm{b}}$ & $0.78^{c}$ & $0.75^{c}$ & $1.63^{f}$ & $1.00^{\mathrm{de}}$ & 0.99 de & $0.25^{\mathrm{a}}$ & $0.94^{\mathrm{d}}$ & $0.89^{\mathrm{d}}$ & $0.51^{\mathrm{b}}$ & $0.59^{b}$ & $1.04^{\mathrm{e}}$ & $0.93^{\mathrm{d}}$ & $1.08^{\mathrm{e}}$ & $0.79^{c}$ \\
\hline 25 & Coniferyl aldehyde & $0.42^{\mathrm{d}}$ & $0.16^{\mathrm{b}}$ & $0.39^{\mathrm{cd}}$ & $0.56^{\mathrm{e}}$ & $0.31^{\mathrm{c}}$ & $0.75^{\mathrm{f}}$ & $0.08^{\mathrm{a}}$ & $0.39^{\mathrm{cd}}$ & $1.19 \mathrm{~g}$ & $0.27^{b c}$ & $0.51^{\mathrm{e}}$ & $0.23^{b}$ & $1.13^{\mathrm{g}}$ & $0.26^{b c}$ & $0.53^{\mathrm{e}}$ \\
\hline \multirow[t]{3}{*}{26} & Aesculetin & $0.32^{\mathrm{d}}$ & $0.14^{\mathrm{b}}$ & $0.30^{\mathrm{d}}$ & $0.47^{\mathrm{e}}$ & $0.25^{\mathrm{cd}}$ & $0.59^{\mathrm{f}}$ & $0.07^{\mathrm{a}}$ & $0.32^{\mathrm{d}}$ & $0.98^{\mathrm{g}}$ & $0.24^{\mathrm{cd}}$ & $0.44^{\mathrm{e}}$ & $0.16^{\mathrm{b}}$ & $0.94^{\mathrm{g}}$ & $0.20 \mathrm{bc}$ & $0.43^{\mathrm{e}}$ \\
\hline & Total & 10.78 & 8.69 & 11.18 & 15.27 & 11.49 & 15.78 & 3.80 & 12.96 & 32.31 & 10.33 & 12.06 & 11.60 & 15.50 & 18.68 & 11.13 \\
\hline & Total of all & 276.09 & 189.84 & 238.55 & 375.62 & 235.87 & 445.57 & 89.98 & 260.96 & 376.62 & 227.73 & 257.34 & 291.83 & 345.78 & 375.53 & 232.07 \\
\hline
\end{tabular}

Different letter in the same row denotes a significant difference between clones according to the Tukey's test, $p<0.05$; “- ${ }^{\prime}$ stands for not detected compound. 


\subsection{Principal Component Analysis}

A principal component analysis (PCA) was used to establish differences among pollen samples of sour cherry clones according to their chemical compositions. Two procedures were performed separately on the quantified polyphenols (Figure 1A,B), and carbohydrates (Figure 2A-F). The initial matrices 15 (the number of pollen samples from the clones) $\times 26$ (quantified polyphenols), and 15 (the number of pollen samples) $\times 10$ (quantified carbohydrates) were processed using the covariance matrix with autoscaling.

PCA carried out on polyphenols resulted in six PCs explaining $94.41 \%$ of the total variability. The first principal component accounted for $49.87 \%$, the second $19.35 \%$, and the third component $9.19 \%$ of the total variance. Although the majority of pollen samples were located in the central part of the PCA correlation plots (Figure 1A), some clones were distinguished from the other pollen samples. Clone VIII/1 separated from the other pollen samples based on its high content of many compounds (ellagic acid, cinnamic acid, aesculetin, coniferyl aldehyde, naringin, p-coumaric acid, aesculin, apiin, p-hydroxybenzoic acid, caffeic acid, protocatechuic acid, chlorogenic acid, and vanillic acid; Figure 1B). Higher contents of syringic acid, sinapic acid, and astragalin were the most important factors in distinguishing clone IV/8 from the other pollen samples, while catechin, rutin, hyperoside, and phlorizin were responsible for the separation clone III/9. On the other hand, clone V/P was separated according to lower contents of almost all quantified polyphenols.
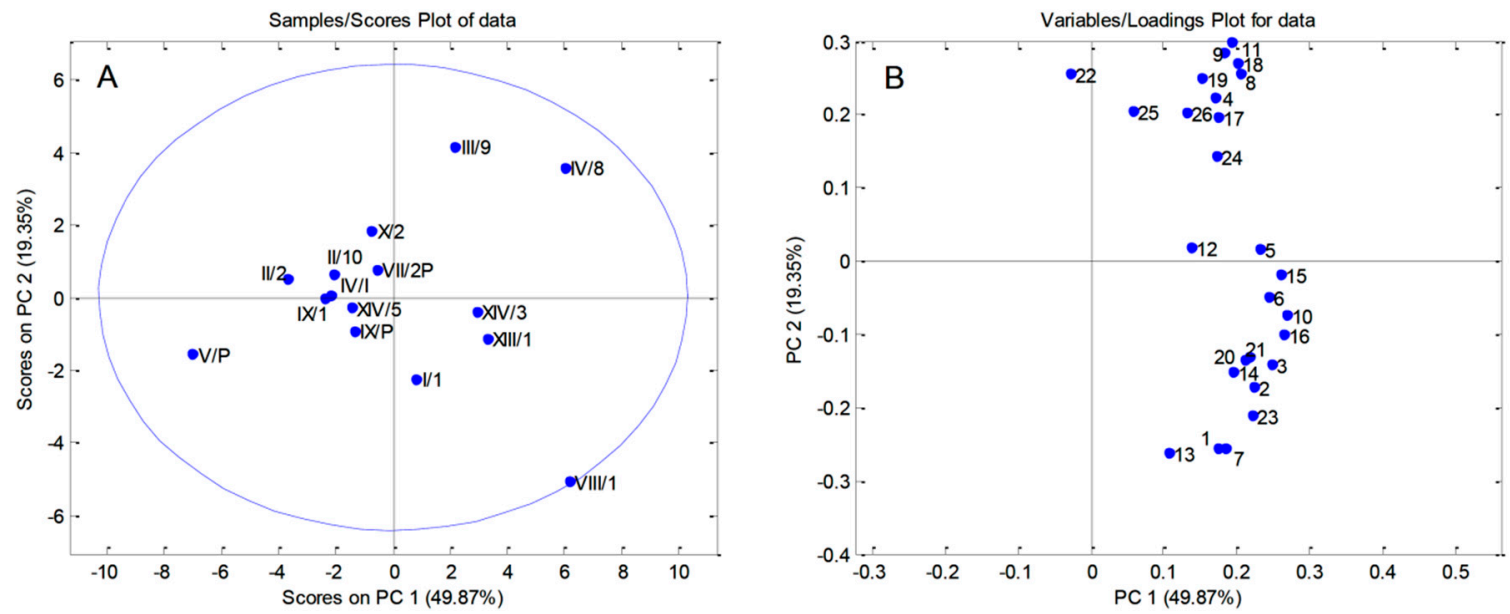

Figure 1. Principal component (PC) scores and loadings plot on quantified polyphenols (A,B) from pollen samples of 15 'Oblačinska' sour cherry clones. Numbers on (B) correspond to the quantified polyphenols as given in Table 4 .

PCA applied on sugar contents produced a five PCs model that explained $78.41 \%$ of the variation of the data set. The first principal component accounted for $22.70 \%$, the second $16.30 \%$, the third $16.21 \%$, the forth $12.61 \%$, and the fifth $10.59 \%$ of the total variance. The PCA correlations plots and loadings plots for the first three principal components are shown in Figure 2. As it can be seen from the PC1/PC2 scores plot (Figure 2A), a differentiation of the pollen samples was not possible based on the sugar contents. Pollen VIII/1 distinguished from the other samples along the PC2 axis (Figure 2A) by its higher contents of maltotriose, sorbitol, and trehalose (Figure 2B). PC1/PC3 and PC2/PC3 scores plots showed separation of clone VII/2P along the PC3 axis (Figure 2C,E). Notably lower levels of fructose and maltose are the most important factors responsible for the separation of clone VII/2P from the other samples (Figure 2D,F). 

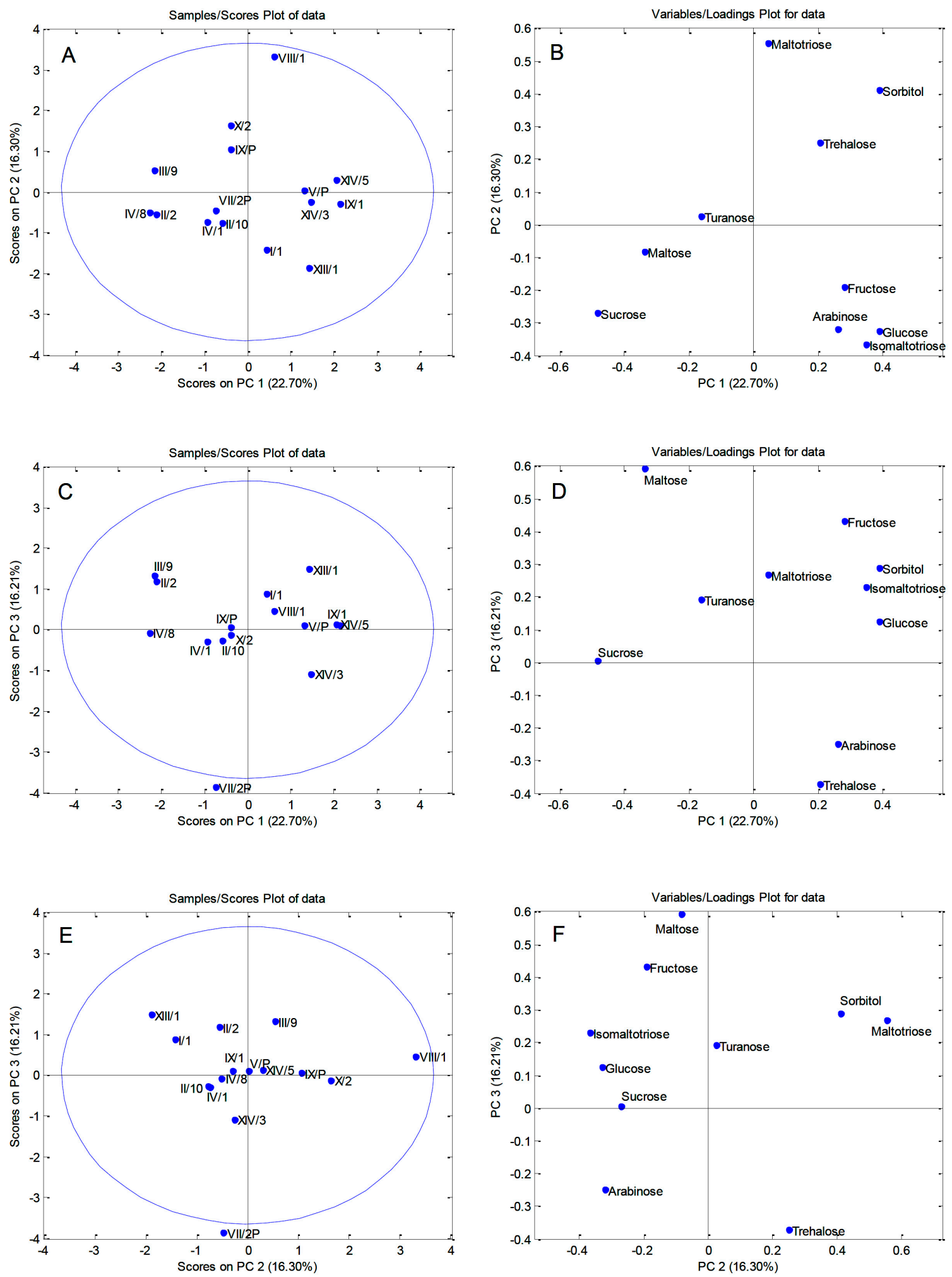

Figure 2. Principal component analysis (PCA) performed on sugar contents in pollen samples of 'Oblačinska' sour cherry clones: Scores plots of the first three principal components $(\mathbf{A}, \mathbf{C}, \mathbf{E})$ and loadings plots $(\mathbf{B}, \mathbf{D}, \mathbf{F})$.

\section{Conclusions}

High sugar and phenolic compounds content (especially rutin, chlorogenic, caffeic, and $p$-coumaric acid) proved that pollen formed clones IV/8, XV/3, and VIII/1 that had high antioxidative potential. 
Samples of pollen analyzed in this experiment were well distinguished with a PCA analysis Based on this it was clarified that all examined clones of 'Oblačinska' sour cherry showed a different chemical profile. This tells us that 'Oblačinska' sour cherry was not a cultivar but a population of different genotypes, which showed big variability due to both generative and vegetative propagation during the last decades.

Although comparison of our results with the published literature was practically impossible, since no work on the sour cherry handpicked pollen was published so far, especially not in the way it was done in the framework of this study, but we found this investigation very important. Knowledge about its active components could have a positive influence on human health because pollen can be used as an apitherapeutic product, to support pharmacological treatment, in prevention and/or curing of diseases, or as a 'super food'. Chemical, nutritional, and microbiological traits of 'Oblačinska' sour cherry pollen can give us some new beneficial usages in medicinal regimes.

Author Contributions: Conceptualization, M.F.A. and M.M.; methodology and writing, M.F.A. and M.N.; validation and investigation, U.G. and T.T.; formal analysis, M.S. and D.D.Z.; writing, review and editing, M.M.

Funding: This study was supported by the Ministry of Education, Science and Technological Development of the Republic of Serbia (projects No. 172017 and TR31063) and Research Council of Norway (project No. 280376).

Conflicts of Interest: The authors declare no conflict of interest.

\section{References}

1. Castro, A.J.; Clément, C. Sucrose and starch catabolism in the anther of Lilium during its development: A comparative study among the anther wall, locular fluid and microspore/pollen fractions. Planta 2007, 225, 1573-1582. [CrossRef] [PubMed]

2. Edlund, A.F.; Swanson, R.; Preuss, D. Pollen and stigma structure and function: The role of diversity in pollination. Plant Cell 2004, 16, S84-S97. [CrossRef] [PubMed]

3. Hafidh, S.; Fíla, J.; Honys, D. Male gametophyte development and function in angiosperms: A general concept. Plant Reprod. 2016, 29, 31-51. [CrossRef] [PubMed]

4. Almaraz-Abarca, N.; Campos, M.G.; Avila-Reyes, J.A. Variability of antioxidant activity among honeybee-collected pollen of different botanical origin. J. Sci. Technol. Am. 2004, 29, 574-578.

5. Stanley, R.G.; Linskens, H.F. Pollen: Biology Biochemistry Management; Springer Science Business Media: Heidelberg, Germany, 1974.

6. Rzepecka-Stojko, A.; Stojko, J.; Kurek-Górecka, A.; Górecki, M.; Kabała-Dzik, A.; Kubina, R.; Moździerz, A.; Buszman, E. Polyphenols from Bee Pollen: Structure, Absorption, Metabolism and Biological Activity. Molecules 2015, 20, 21732-21749. [CrossRef] [PubMed]

7. Nepi, M.; Franchi, G.G.; Pacini, E. Pollen hydration status at dispersal: Cytophysiological features and strategies. Protoplasma 2001, 216, 171-180. [CrossRef]

8. Bogdanov, S. Pollen: Collection, harvest, composition, quality. The Pollen Book. 2012. Chapter 1. Available online: http://www.bee-hexagon.net/ (accessed on 23 January 2019).

9. Nicolson, S.W.; Human, H. Chemical composition of the 'low quality' pollen of sunflower (Helianthus annuus L., Asteraceae). Apidologie 2013, 44, 144-152. [CrossRef]

10. Li, C.; Xu, B.; Wang, Y.; Feng, Q.; Yang, W. Effects of dietary crude protein levels on development, antioxidant status, and total midgut protease activity of honey bee (Apis mellifera ligustica). Apidologie 2012, 43, 576-586. [CrossRef]

11. Manning, R. Fatty acids in pollen: A review of their importance for honeybees. Bee World 2001, 82, 60-75. [CrossRef]

12. Singh, S.; Saini, K.; Jain, K.L. Quantitative comparison of lipids in some pollens and their phagostimulatory effects in honey bees. J. Apic. Res. 1999, 38, 87-92. [CrossRef]

13. Szczesna, T. Long chain fatty acids composition of honeybee-collected pollen. J. Apic. Sci. 2006, 50, 65-79.

14. Zhang, H.; Wang, X.; Wang, K.; Li, C. Antioxidant and tyrosinase inhibitory properties of aqueous ethanol extracts from monofloral bee pollen. J. Apic. Sci. 2015, 59, 119-128. [CrossRef]

15. Irwin, R.E.; Adler, L.S.; Brody, A.K. The dual role of floral traits: Pollinator attraction and plant defense. Ecology 2004, 85, 1503-1511. [CrossRef] 
16. Richardson, L.L.; Adler, L.S.; Leonard, A.S.; Andicoechea, J.; Regan, K.H.; Anthony, W.E.; Manson, J.S.; Irwin, R.E. Secondary metabolites in floral nectar reduce parasite infections in bumblebees. Proc. R. Soc. Lond. B Biol. Sci. 2015, 282, 20142471. [CrossRef]

17. Lecocq, A.; Green, A.A.; Pinheiro De Castro, É.C.; Olsen, C.E.; Jensen, A.B.; Zagrobelny, M. Honeybees Tolerate Cyanogenic Glucosides from Clover Nectar and Flowers. Insects 2018, 9, 31. [CrossRef]

18. Palmer-Young, E.C.; Sadd, B.M.; Stevenson, P.C.; Irwin, R.E.; Adler, L.S. Bumble bee parasite strains vary in resistance to phytochemicals. Sci. Rep. 2016, 6, 37087. [CrossRef]

19. Firon, N.; Nepi, M.; Pacini, E. Water status and associated processes mark critical stages in pollen development and functioning. Ann. Bot. 2012, 109, 1201-1214. [CrossRef]

20. Almeida-Muradian, L.B.; Pamplona, L.C.; Coimbra, S.; Barth, O.M. Chemical composition and botanical evaluation of dried bee pollen pellets. J. Food Compos. Anal. 2005, 18, 105-111. [CrossRef]

21. Brodschneider, R.; Crailsheim, K. Nutrition and health in honey bees. Apidologie 2010, 41, 278-294. [CrossRef]

22. Morgano, M.A.; Martins, M.C.T.; Rabonato, L.C.; Milani, R.F.; Yotsuyanagi, K.; Rodriguez-Amaya, D.B. A comprehensive investigation of the mineral composition of Brazilian bee pollen: Geographic and seasonal variations and contribution to human diet. J. Braz. Chem. Soc. 2012, 23, 727-736. [CrossRef]

23. Dötterl, S.; Vereecken, N.J. The chemical ecology and evolution of bee-flower interactions: A review and perspectives. Can. J. Zool. 2010, 88, 668-697. [CrossRef]

24. Dyer, A.G.; Paulk, A.C.; Reser, D.H. Colour processing in complex environments: Insights from the visual system of bees. Proc. Biol. Sci. 2011, 278, 952-959. [CrossRef]

25. Sedivy, C.; Muüller, A.; Dorn, S. Closely related pollen generalist bees differ in their ability to develop on the same pollen diet: Evidence for physiological adaptations to digest pollen. Funct. Ecol. 2011, 25, 718-725. [CrossRef]

26. Vanderplanck, M.; Vereecken, N.J.; Grumiau, L.; Esposito, F.; Lognay, G.; Wattiez, R.; Michez, D. The importance of pollen chemistry in evolutionary host shifts of bees. Sci. Rep. 2017, 7, 43058. [CrossRef]

27. Morais, M.; Moreira, L.; Feás, X.; Estevinho, L.M. Honeybee-collected pollen from five Portuguese Natural Parks: Palynological origin, phenolic content, antioxidant properties and antimicrobial activity. Food Chem. Toxicol. 2011, 49, 1096-1101. [CrossRef]

28. Alaux, C.; Dantec, C.; Parrinello, H.; Le Conte, Y. Nutrigenomics in honey bees: Digital gene expression analysis of pollen's nutritive effects on healthy and varroa-parasitized bees. BMC Genom. 2011, 12, 496. [CrossRef]

29. Degrandi-Hoffman, G.; Chen, Y.; Huang, E.; Huang, M.H. The effect of diet on protein concentration, hypopharyngeal gland development and virus load in worker honey bees (Apis mellifera L.). J. Insect Physiol. 2010, 56, 1184-1191. [CrossRef]

30. Vásquez, A.; Olofsson, T.C. The lactic acid bacteria involved in the production of bee pollen and bee bread. J. Apic. Res. Bee World 2009, 48, 189-195. [CrossRef]

31. Khider, M.; Elbanna, K.; Mahmoud, A.; Owayss, A.A. Egyptian honeybee pollen as antimicrobial, antioxidant agents, and dietary food supplements. Food Sci. Biotechnol. 2013, 22, 1-9. [CrossRef]

32. Solgajová, M.; Ivanišová, E.; Nôžkova, J.; Frančáková, H.; Tóth, Ž.; Dráb, Š. Antioxidant activity and polyphenol content of malt beverages enriched with bee pollen. J. Microbiol. Biotech. Food Sci. 2014, 3, 281-284.

33. Mărgăoan, R.; Mărghitaş, L.A.; Dezmirean, D.; Mihai, C.M.; Bobiş, O. Bee collected pollen-general aspects and chemical composition. Bull. Univ. Agric. Sci. Vet. 2010, 67, 254-259.

34. Haro, A.; López-Aliaga, I.; Lisbona, F.; Barrionuevo, M.; Alférez, M.J.; Campos, M.S. Beneficial effect of pollen and/or propolis on the metabolism of iron, calcium, phosphorus, and magnesium in rats with nutritional ferropenic anemia. J. Agric. Food Chem. 2000, 48, 5715-5722. [CrossRef]

35. Denisow, B.; Denisow-Pietrzyk, M. Biological and therapeutic properties of bee pollen: A review. J. Sci. Food Agric. 2016, 96, 4303-4309. [CrossRef]

36. Komosinska-Vassev, K.; Olczyk, P.; Kaźmierczak, J.; Mencner, L.; Olczyk, K. Bee pollen chemical composition and therapeutic application. J. Evid. Based Complement. Altern. Med. 2015, 2015, 297425. [CrossRef]

37. Hamamoto, R.; Ishiyama, K.; Yamaguchi, M. Inhibitory effects of bee pollen Cistus ladaniferus extract on bone resorption in femoral tissues and osteoclast-like cell formation in bone marrow cells in vitro. J. Health Sci. 2006, 52, 268-275. [CrossRef] 
38. Estevinho, L.M.; Rodrigues, S.; Pereira, A.P.; Feaás, X. Portuguese bee pollen: Palynological study nutritional and microbiological evaluation. Int. J. Food Sci. Technol. 2012, 47, 429-435. [CrossRef]

39. Park, H.K.; Kim, S.K.; Lee, S.W.; Chung, J.H.; Lee, B.C.; Na, S.W.; Park, C.G.; Kim, Y.O. A herbal formula, comprising Panax ginseng and bee-pollen, inhibits development of testosterone induced benign prostatic hyperplasia in male Wistar rats. Saudi J. Biol. Sci. 2017, 24, 1555-1561. [CrossRef]

40. Al-Salem, H.S.; Bhat, R.S.; Al-Ayadhi, L.; El-Ansary, A. Therapeutic potency of bee pollen against biochemical autistic features induced through acute and sub-acute neurotoxicity of orally administered propionic acid. BMC Complement. Altern. Med. 2016, 16, 120. [CrossRef]

41. Spulber, R.; Vladu, M.G.; Popa, O.; Băbeanu, N. Phenolic content and potential inhibitory activity of Romanian bee pollen on different plant pathogenic strains. Sci. Bull. Ser. F Biotechnol. 2017, 21, 104-108.

42. Food and Agriculture Organization Corporate Statistical Database. 2019. Available online: http://www.fao. org/faostat/en/\#data/QC (accessed on 23 June 2019).

43. Rakonjac, V.; Fotirić Akšić, M.; Nikolić, D.; Milatović, D.; Čolić, S. Morphological characterization of 'Oblačinska' sour cherry by multivariate analysis. Sci. Hortic. 2010, 125, 679-684. [CrossRef]

44. Alrgei, H.O.; Dabić, D.; Natić, M.; Rakonjac, V.; Milojković-Opsenica, D.; Tešić, Ž.; Fotirić Akšić, M. Chemical profile of major taste- and health-related compounds of (Oblačinska) sour cherry. J. Sci. Food Agric. 2016, 63, 7476-7486. [CrossRef]

45. Guffa, B.; Nedić, N.; Dabić Zagorac, D.; Tosti, T.; Gašić, U.; Natić, M.; Fotirić Akšić, M. Characterization of Sugar and Polyphenolic Diversity in Floral Nectar of Different 'Oblacinska' Sour Cherry Clones. Chem. Biodivers. 2017, 14, e1700061. [CrossRef]

46. Meier, U.; Graf, H.; Hack, H.; Hess, M.; Kennel, W.; Klose, R.; Mappes, D.; Seipp, D.; Stauß, R.; Streif, J.; et al. Phanologische Entwicklungsstadien des Kernobstes (Malus domestica Borkh. und Pyrus communis L.), des Steinobstes (Prunus-Arten), der Johannisbeere (Ribes-Arten) und der Erdbeere (Fragaria $\times$ ananassa Duch.). Nachr. Des. Dtsch. Pflanzenschutzd. 1994, 46, 141-153.

47. Yadav, S.K.; Singh, V.; Jyothi Lakshmi, N.; Vanaja, M.; Maheswari, M.; Tiwari, Y.K.; Patil, A.; Nagendram, E.; Venkateswarlu, B. Carbohydrates and Sucrose Metabolizing Enzymes in the Leaves of Vigna mungo Genotypes as Influenced by Elevated $\mathrm{CO}_{2}$ Concentration. J. Agric. Sci. Technol. 2013, 15, 1107-1120.

48. Taha, E.K.A. Chemical Composition and Amounts of Mineral Elements in Honeybee-Collected Pollen in Relation to Botanical Origin. J. Apic. Sci. Vol. 2015, 59, 75-81. [CrossRef]

49. Nicholls, E.K.; Ehrendreich, D.; de Ibarra, N.H. Differences in color learning between pollen- and sucrose-rewarded bees. Commun. Integr. Biol. 2015, 8, e1052921. [CrossRef]

50. Figueroa, C.G.; Iturriaga, G.; Valenzuela, E.M. Actividad de trehalosa 6-fosfato sintasa en plantas de selaginella lepidophylla en respuesta a hidratación y desecación. Rev. Fitotec. Mex. 2004, 27, 17-22.

51. Bogdanov, S. Contaminants of bee products. Apidologie 2006, 37, 1-18. [CrossRef]

52. Negri, G.; Teixeira, E.W.; Alves, M.L.; Moreti, A.C.; Otsuk, I.P.; Borguini, R.G.; Salatino, A. Hydroxycinnamic acid amide derivatives, phenolic compounds and antioxidant activities of extracts of pollen samples from Southeast Brazil. J. Agric. Food Chem. 2011, 59, 5516-5522. [CrossRef]

53. Serra Bonvehí, J.; Soliva Torrentó, M.; Centelles Lorente, E. Evaluation of polyphenolic and flavonoid compounds in honeybee-collected pollen produced in Spain. J. Agric. Food Chem. 2001, 49, 1848-1853. [CrossRef]

54. Tajik, N.; Tajik, M.; Mack, I.; Enck, P. The potential effects of chlorogenic acid, the main phenolic components in coffee, on health: A comprehensive review of the literature. Eur. J. Nutr. 2017, 56, 2215-2244. [CrossRef]

55. Magnani, C.; Isaac, V.L.B.; Correa, M.A.; Salgado, H.R.N. Caffeic acid: A review of its potential use in medications and cosmetics. Anal. Methods 2014, 6, 3203-3210. [CrossRef]

56. Akdemir, M.; Okulu, K.; Kösemehmetoglu, K.; Ener, K.; Topal, F.; Evirgen, O.; Gürleyik, E.; Avci, A. Evaluation of the protective effect of quercetin against cisplatin-in-duced renal and testis tissue damage and sperm parameters in rats. Andrologia 2014, 46, 1089-1097. [CrossRef]

57. Dias, L.G.; Tolentino, G.; Pascoal, A.; Estevinho, L.M. Effect of processing conditions on the bioactive compounds and biological properties of bee pollen. J. Apic. Res. 2016, 55, 357-365. [CrossRef]

58. Ganeshpurkar, A.; Saluja, A.K. The Pharmacological Potential of Rutin. Saudi Pharm. J. 2017, 25, $149-164$. [CrossRef] 
59. Graikou, K.; Kapeta, S.; Aligiannis, N.; Sotiroudis, G.; Chondrogianni, N.; Gonos, E.; Chinou, I. Chemical analysis of Greek pollen-Antioxidant, antimicrobial, and proteasome activation properties. Chem. Cent. J. 2011, 5, 33. [CrossRef]

60. Al-Samarrai, R.R.H.; Al-Samarrai, A.M.H.; Al-Salihi, F.G. Identification of Flavonoids in Iraqi Date Palm Pollen by HPLC. Orient. J. Chem. 2017, 33, 985-988. [CrossRef]

61. Tattini, M.; Di Ferdinando, M.; Brunetti, C.; Goti, A.; Pollastri, S.; Bellasio, C.; Giordano, C.; Fini, A.; Agati, G. Esculetin and esculin (esculetin 6-O-glucoside) occur as inclusions and are differentially distributed in the vacuole of palisade cells in Fraxinus ornus leaves: A fluorescence microscopy analysis. J. Photochem. Photobiol. B 2014, 140, 28-35. [CrossRef]

(C) 2019 by the authors. Licensee MDPI, Basel, Switzerland. This article is an open access article distributed under the terms and conditions of the Creative Commons Attribution (CC BY) license (http://creativecommons.org/licenses/by/4.0/). 